\title{
Judicious Nitrogen Management using Leaf Colour Chart for Enhancing Growth and Yield of Short Duration Transplanted Rice (Oryza sativa L)
}

\author{
B. Bhavana ${ }^{1 *}$, P. Laxminarayana ${ }^{1}$, A. Madhavi Latha ${ }^{1}$ and T. Anjaiah ${ }^{2}$ \\ ${ }^{1}$ Department of Agronomy, ${ }^{2}$ Department of Soil Science \& Agricultural Chemistry, \\ College of Agriculture, PJTSAU, Rajendranagar, Hyderabad, Telangana -500030, India \\ *Corresponding author
}

\section{A B S T R A C T}

\begin{tabular}{|l|}
\hline Keyw ord s \\
LCC, Nitrogen, \\
Short duration rice, \\
Oryza sativa $L$, \\
Growth, SPAD \\
\hline Article Info \\
\hline Accepted: \\
20 May 2020 \\
Available Online: \\
10 June 2020 \\
\hline \hline
\end{tabular}

Field investigation was carried out during Kharif, 2018 with an objective to study the possibility of effect of LCC based nitrogen management on growth of transplanted rice. Treatments included two doses of nitrogen (120 and $\left.150 \mathrm{~kg} \mathrm{ha}^{-1}\right)$ applied on basis of LCC- 3 and 4 . In turn Nitrogen was applied in 3 equal splits@ $120 \mathrm{~kg} \mathrm{~N} \mathrm{ha}^{-1}$ and (3 and 4) splits with half as basal, remaining @ $150 \mathrm{Kg} \mathrm{ha}^{-1}$. These treatments were evaluated against control, recommended method and Farmers practice with (120-6040), (180-80-40) RDF respectively applied at fixed time intervals. Results revealed that, $\mathrm{N}$ application based on LCC value-4 was more beneficial than LCC-3 in enhancing the growth and yield of rice. LCC-4 at $150 \mathrm{~kg} \mathrm{~N} \mathrm{ha}^{-1}\left(\mathrm{~T}_{9}\right)$ produced significantly higher plant height $(107.9 \mathrm{~cm})$ at maturity, number of tillers $\left(339 \mathrm{~m}^{-2}\right)$, leaf area index (2.17), SPAD readings (34.3), dry matter $\left(11,246 \mathrm{~kg} \mathrm{ha}^{-1}\right)$ and grain yield $\left(6,533 \mathrm{~kg} \mathrm{ha}^{-1}\right)$. With respect to dose of nitrogen $150 \mathrm{~kg} \mathrm{~N}^{-1}$ resulted in more yield than $120 \mathrm{~kg} \mathrm{~N} \mathrm{ha}^{-1}$. The results of the study implied that LCC-4 was found to be effective as a decision tool for optimum $\mathrm{N}$ application in rice.

\section{Introduction}

Rice (Oryza sativa L.) is the most important source of staple food in India, occupying 43.5 $\mathrm{m}$ ha of area producing $104.41 \mathrm{~m}$ tonnes with productivity of $3.60 \mathrm{t} \mathrm{ha}^{-1}$ (Directorate of Economics and Statistics 2016-17). Telangana contributes $2.09 \mathrm{~m}$ ha area with a production of $6.62 \mathrm{~m}$ tonnes, with an average productivity of $3.295 \mathrm{t} \mathrm{ha}^{-1}$ during 2016-17 (Season and Crop report Telangana, 2016-17).
About $90 \%$ of total rice produced is consumed in Asian countries, but the productivity of rice in India is comparatively very low than other major rice growing countries in the world (6.71 t ha ${ }^{-1}$ - china).

Among all the reasons for lower productivity, inefficient utilisation of nitrogen is considered as an important one. Extensive adaption of modern varieties and improved production technology has accelerated the use of 
chemical fertilizers especially of nitrogen. Nitrogen is the most important nutrient that limits the high yield potential of rice cultivars (Shreshta and Maskey. 2005). Farmers generally apply excess nitrogen (and little Phosphorus, potassium and other nutrients) which will eventually result in high pest and disease incidence due to excess vegetative growth and also leads to serious lodging.

For most soils of the country, nitrogen use efficiency in rice is only about 30 to $40 \%$ and about $1 / 3$ rd of applied nitrogen is lost by different losses (Abrol et al., 2007). Optimum use of nitrogen can be achieved by matching nitrogen supply with crop demand. Precise application of nitrogen fertilizer based on plant need and location in the field will greatly help in improving the fertilizer use efficiency in rice.

A simple, quick and non-destructive method for estimating the plant nitrogen demand is LCC (leaf colour chart) and Soil Plant Analysis Development (SPAD)- chlorophyll meter. Leaf Colour Chart will provide indirect assessment of leaf nitrogen status, which is closely related to photosynthetic rate and biomass production (Kropff et al., 1993). Direct measurement of leaf nitrogen content by laboratory methods are time taking, laborious and expensive. Because of delay in time between the sampling and results, the laboratory methods are limited in use.

Among the non-destructive methods of leaf nitrogen content estimation, LCC is more simple and quick tool. High price of SPAD limits it's use by the farmers and hence LCC can be better option for farmers in estimating the leaf nitrogen status easily.

Due to shift (delay) in monsoons from $2^{\text {nd }}$ week of June to last week of June/ $1^{\text {st }}$ week of July, farmers choice of varieties changes from long duration varieties to short duration varieties. This short duration varieties unlike medium/long duration varieties require less quantity of nitrogen fertilizer. Farmers instead apply same dose of nitrogen fertilizer in same manner as required by medium/long duration varieties which leads to application of nitrogen even after panicle initiation stage. This results in heavy lodging, pest and disease incidence due to excess vegetative growth eventually resulting in low yields. Hence there is a need to work out on quantity \& time of application of nitrogen in short duration rice varieties.

\section{Materials and Methods}

A field experiment was conducted during Kharif, 2017 to study the effect of LCC based nitrogen management on growth, yield and nitrogen use efficiency of short duration transplanted rice at College farm, College of Agriculture, Rajendranagar, Hyderabad ( $17^{\circ} 19^{\prime} \mathrm{N}$ and $\left.78^{\circ} 24^{\prime} \mathrm{E}\right)$.

The soil was moderately alkaline in $\mathrm{pH}$ (7.8), non-saline in EC $\left(0.32 \mathrm{dSm}^{-1}\right)$, low in organic carbon $(0.42 \%)$, low in available $\mathrm{N}(210 \mathrm{~kg}$ $\left.\mathrm{ha}^{-1}\right)$, medium in available $\mathrm{P}_{2} \mathrm{O}_{5}\left(44.3 \mathrm{~kg} \mathrm{ha}^{-1}\right)$ and high in available $\mathrm{K}_{2} \mathrm{O}\left(351 \mathrm{~kg} \mathrm{ha}^{-1}\right)$. The experiment was laid out in RBD with three replications. Treatments included two doses of nitrogen (120 and $150 \mathrm{~kg} \mathrm{ha}^{-1}$ ) applied on basis of two critical LCC values- 3 and 4 .

In turn $\mathrm{N}$ was applied in 3 equal splits incase of $120 \mathrm{~kg} \mathrm{~N} \mathrm{ha}^{-1}$ and with $150 \mathrm{~kg} \mathrm{~N} \mathrm{ha}^{-1}$ it was applied in 3 and 4 splits with half as basal. These LCC based treatments were evaluated against control with no nitrogen, Recommended method and Farmers practice with (120-60-40), (180-80-40) RDF respectively applied at fixed time intervals. Rice variety selected for the study was KNM118 (Kunaram sannalu). All agronomic practices were carried out as per the recommendations. 


\section{Nutrient management}

The recommended dose of fertilizer @ (12060-40) and (180-80-40) N, $\mathrm{P}_{2} \mathrm{O}_{5}$ and $\mathrm{K}_{2} \mathrm{O} \mathrm{kg}$ $\mathrm{ha}^{-1}$ were applied to $\mathrm{T}_{2}$ and $\mathrm{T}_{3}$ treatments respectively. NPK were applied through urea, single super phosphate and Muriate of potash (single super phosphate for control) sources respectively. Half of the recommended dose of $\mathrm{N}$ was applied as basal for all treatments except for $\mathrm{T}_{4}$ and $\mathrm{T}_{7}$.

Entire dose of $\mathrm{P}$ as basal and $\mathrm{K}$ applied in 2 splits (basal + at $1^{\text {st }}$ top dressing of Nitrogen) for all treatments. RDN was applied at 0,18 , 35 DAT for $T_{2}$ and $T_{3}$. For treatments $T_{4}$ to $\mathrm{T}_{9}$, nitrogen was applied based on their respective LCC critical values using RDN of $120 \mathrm{~kg} \mathrm{ha}^{-1}$ for $\mathrm{T}_{4}$ and $\mathrm{T}_{7}$ and RDN of 150 for $\mathrm{T}_{5}, \mathrm{~T}_{6}, \mathrm{~T}_{8}$ and $\mathrm{T}_{9}$ treatments.

\section{LCC observation}

The topmost fully expanded leaf from each hill was selected and leaf colour was compared by placing the middle part of the leaf on LCC and the leaf colour was observed. Whenever the green colour of more than 5 out of 10 leaves were observed equal to or below a set critical limit of LCC score, nitrogen was applied as per the treatment. The leaf was not detached or destroyed. The average LCC reading were determined for each treatment. Readings were taken in the morning (8-10 AM) under the shade of body in order to avoid the influence of sun light as it may reflect the LCC colour.

Observations on plant height, Leaf area, Leaf Area Index, tillers, dry matter production, SPAD readings, Days to $50 \%$ flowering and grain yield during maturity stage were done. Five hills per plot were randomly marked with wooden sticks and tagged with luggage labels for recording various observations pertaining to the growth parameters.

\section{Results and Discussion}

\section{Effect of LCC based $\mathrm{N}$ management on growth parameters of rice}

The data depicted in the Table. 1 showed significant variation in growth components of rice Viz., plant height, Leaf area, Leaf Area Index, Dry matter production and Tillers $\mathrm{m}^{-2}$. The plant height increased progressively with the growth of crop. At harvest highest plant height $(111.3 \mathrm{~cm})$ was recorded with $\mathrm{T}_{3}$ \{Farmers practice $\left(180-80-40 \mathrm{Kg} \mathrm{N}, \mathrm{P}_{2} \mathrm{O}_{5}\right.$, $\mathrm{K}_{2} \mathrm{O}$ ha $\left.^{-1}\right)$ - RDN applied as 1 basal +2 equal splits $(1 / 2$ basal $+1 / 4$ th $+1 / 4$ th $)\}$ and was on par with treatments $\mathrm{T}_{7}, \mathrm{~T}_{8}, \mathrm{~T}_{9}$ and $\mathrm{T}_{2}$. The lowest plant height $(75.4 \mathrm{~cm})$ was recorded in treatment which received No nitrogen. It was also observed that treatments imposed at LCC critical value $4\left(T_{7}\right.$ to $\left.T_{9}\right)$ recorded more plant height over LCC-3 treatments ( $T_{4}$ to $T_{6}$ ).

As nitrogen is directly associated with plant metabolism and vegetative growth. Hence application of more nitrogen results in increased vegetative growth due to meristematic growth, cell division and cell elongation of internodes thus contributing to higher growth rate of stem. Similar results were reported by Ali et al., 2012. Leaf area and Leaf area index (LAI) increased rapidly upto panicle initiation but decreased at harvest.

This could be due to senescence of leaves after the reproductive phase. Highest Leaf area and LAI $\left(372.2 \mathrm{~cm}^{2}\right.$ and 2.48) was recorded with $\mathrm{T}_{3}$ - Farmers practice (180-80$40 \mathrm{Kg} \mathrm{N}, \mathrm{P}_{2} \mathrm{O}_{5}, \mathrm{~K}_{2} \mathrm{O} \mathrm{ha}^{-1}$ ) which might be due to sufficient availability of nitrogen for producing larger cells with thinner cell walls thereby resulting in efficient cell division and elongation, ultimately producing higher photosynthetic area (Patel et al., 2018). Lowest $\left(188.1 \mathrm{~cm}^{2}\right.$ and 1.25$)$ was recorded with $\mathrm{T}_{1}$ (No Nitrogen). 
Table.1 Effect of LCC based nitrogen management on growth parameters of rice

\begin{tabular}{|c|c|c|c|c|c|c|}
\hline \multicolumn{2}{|r|}{ Treatments } & \multirow{2}{*}{$\begin{array}{c}\begin{array}{c}\text { Plant } \\
\text { height } \\
(\mathbf{c m})\end{array} \\
75.4\end{array}$} & \multirow{2}{*}{$\begin{array}{c}\begin{array}{c}\text { Leaf area } \\
\left(\mathbf{c m}^{2}\right)\end{array} \\
188.1\end{array}$} & \multirow{2}{*}{$\begin{array}{c}\begin{array}{c}\text { Leaf Area } \\
\text { Index }\end{array} \\
1.25\end{array}$} & \multirow{2}{*}{$\begin{array}{c}\begin{array}{c}\text { Dry matter } \\
\text { accumulation } \\
\left(\mathbf{k g ~ h a}^{-1}\right)\end{array} \\
5208\end{array}$} & \multirow{2}{*}{$\begin{array}{c}\text { Tillers } \mathbf{~ m}^{-2} \\
242\end{array}$} \\
\hline $\mathbf{T}_{1}$ & No Nitrogen & & & & & \\
\hline $\mathbf{T}_{2}$ & $\begin{array}{l}\mathrm{RDF}\left(120-60-40 \mathrm{Kg} \mathrm{N}, \mathrm{P}_{2} \mathrm{O}_{5}, \mathrm{~K}_{2} \mathrm{O} \text { ha }^{-1}\right)-\mathrm{RDN} \text { applied as } 1 \\
\text { basal }+2 \text { equal splits }\left(1 / 2 \text { basal }+1 / 4^{\text {th }}+1 / 4^{\text {th }}\right)\end{array}$ & 103.0 & 308.3 & 2.06 & 10469 & 316 \\
\hline $\mathbf{T}_{3}$ & $\begin{array}{l}\text { Farmers practice }\left(180-80-40 \mathrm{Kg} \mathrm{N}, \mathrm{P}_{2} \mathrm{O}_{5}, \mathrm{~K}_{2} \mathrm{O} \text { ha }^{-1}\right)-\mathrm{RDN} \\
\text { applied as } 1 \text { basal }+2 \text { equal splits }\left(1 / 2 \text { basal }+1 / 4^{\text {th }}+1 / 4^{\text {th }}\right)\end{array}$ & 111.3 & 372.2 & 2.48 & 11130 & 328 \\
\hline $\mathbf{T}_{4}$ & $\begin{array}{l}120 \mathrm{~kg} \mathrm{RDN} \text { at LCC } 3-\mathrm{RDN} \text { applied as } 3 \text { equal splits } \\
\left(1 / 3^{\text {rd }} \text { basal }+1 / 3^{\text {rd }}+1 / 3^{\text {rd }}\right)\end{array}$ & 92.0 & 278.9 & 1.86 & 8214 & 281 \\
\hline $\mathbf{T}_{5}$ & $\begin{array}{l}150 \mathrm{~kg} \mathrm{RDN} \text { at LCC } 3-\mathrm{RDN} \text { applied as } 1 \text { basal }+2 \text { equal } \\
\text { splits }\left(1 / 2 \text { basal }+1 / 4^{\text {th }}+1 / 4^{\text {th }}\right)\end{array}$ & 94.7 & 279.7 & 1.86 & 8863 & 295 \\
\hline $\mathbf{T}_{6}$ & $\begin{array}{l}150 \mathrm{~kg} \mathrm{RDN} \text { at LCC } 3-\mathrm{RDN} \text { applied as } 1 \text { basal+ } 3 \text { equal } \\
\text { splits }(1 / 2 \text { basal }+25 \mathrm{~kg}+25 \mathrm{~kg}+25 \mathrm{~kg})\end{array}$ & 100.2 & 283.1 & 1.89 & 8923 & 300 \\
\hline $\mathbf{T}_{7}$ & $\begin{array}{l}120 \mathrm{~kg} \mathrm{RDN} \text { at LCC } 4-\mathrm{RDN} \text { applied as } 3 \text { equal splits } \\
\left(1 / 3^{\text {rd }} \text { basal }+1 / 3^{\text {rd }}+1 / 3^{\text {rd }}\right)\end{array}$ & 102.1 & 311.4 & 2.08 & 10565 & 317 \\
\hline $\mathbf{T}_{8}$ & $\begin{array}{l}150 \mathrm{~kg} \mathrm{RDN} \text { at LCC } 4-\mathrm{RDN} \text { applied as } 1 \text { basal+ } 2 \text { equal } \\
\text { splits }\left(1 / 2 \text { basal }+1 / 4^{\text {th }}+1 / 4^{\text {th }}\right)\end{array}$ & 104.2 & 321.9 & 2.15 & 10870 & 320 \\
\hline $\mathbf{T}_{9}$ & $\begin{array}{l}150 \mathrm{~kg} \mathrm{RDN} \text { at LCC } 4-\mathrm{RDN} \text { applied as } 1 \text { basal }+3 \text { equal } \\
\text { splits }(1 / 2 \text { basal }+25 \mathrm{~kg}+25 \mathrm{~kg}+25 \mathrm{~kg})\end{array}$ & 107.9 & 325.7 & 2.17 & 11246 & 339 \\
\hline & $\mathrm{SE}(\mathrm{m}) \pm$ & 2.6 & 9.8 & 0.07 & 515.3 & 10.39 \\
\hline & $\mathrm{CD}(\mathrm{p}=0.05)$ & 7.9 & 29.5 & 0.20 & 1544.7 & 31.15 \\
\hline & $\mathrm{CV} \%$ & 4.6 & 5.8 & 5.8 & 9.4 & 5.9 \\
\hline
\end{tabular}


Table.2 Effect of LCC based nitrogen management on Days to $50 \%$ flowering, SPAD readings, and Grain Yield of rice

\begin{tabular}{|c|c|c|c|c|}
\hline \multicolumn{2}{|r|}{ Treatments } & \multirow{2}{*}{$\begin{array}{c}\text { Days to } 50 \\
\% \\
\text { Flowering } \\
60\end{array}$} & \multirow{2}{*}{$\begin{array}{c}\begin{array}{c}\text { SPAD } \\
\text { readings }\end{array} \\
23.2 \\
\end{array}$} & \multirow{2}{*}{$\begin{array}{c}\begin{array}{c}\text { Grain yield } \\
\text { (kg ha }^{-1} \text { ) }\end{array} \\
2474\end{array}$} \\
\hline $\mathbf{T}_{1}$ & No Nitrogen & & & \\
\hline $\mathbf{T}_{2}$ & $\begin{array}{l}\mathrm{RDF}\left(120-60-40 \mathrm{Kg} \mathrm{N}, \mathrm{P}_{2} \mathrm{O}_{5}, \mathrm{~K}_{2} \mathrm{O} \mathrm{ha}{ }^{-1}\right)-\mathrm{RDN} \text { applied as } 1 \text { basal+ } 2 \\
\text { equal splits }\left(1 / 2 \text { basal }+1 / 4^{\text {th }}+1 / 4^{\text {th }}\right)\end{array}$ & 67 & 29.9 & 5499 \\
\hline $\mathbf{T}_{\mathbf{3}}$ & $\begin{array}{l}\text { Farmers practice }\left(180-80-40 \mathrm{Kg} \mathrm{N}, \mathrm{P}_{2} \mathrm{O}_{5}, \mathrm{~K}_{2} \mathrm{O} \text { ha }^{-1}\right)-\mathrm{RDN} \text { applied } \\
\text { as } 1 \text { basal }+2 \text { equal splits }\left(1 / 2 \text { basal }+1 / 4^{\text {th }}+1 / 4^{\text {th }}\right)\end{array}$ & 70 & 36.0 & 6224 \\
\hline $\mathbf{T}_{4}$ & $\begin{array}{l}120 \mathrm{~kg} \text { RDN at LCC } 3-\mathrm{RDN} \text { applied as } 3 \text { equal splits }\left(1 / 3^{\text {rd }} \text { basal }\right. \\
\left.+1 / 3^{\text {rd }}+1 / 3^{\text {rd }}\right)\end{array}$ & 66 & 28.4 & 3814 \\
\hline $\mathbf{T}_{5}$ & $\begin{array}{l}150 \mathrm{~kg} \mathrm{RDN} \text { at LCC } 3-\mathrm{RDN} \text { applied as } 1 \text { basal }+2 \text { equal splits } \\
\left(1 / 2 \text { basal }+1 / 4^{\text {th }}+1 / 4^{\text {th }}\right)\end{array}$ & 67 & 28.9 & 4342 \\
\hline $\mathbf{T}_{6}$ & $\begin{array}{l}150 \mathrm{~kg} \mathrm{RDN} \text { at LCC } 3-\mathrm{RDN} \text { applied as } 1 \text { basal+ } 3 \text { equal splits }(1 / 2 \\
\text { basal }+25 \mathrm{~kg}+25 \mathrm{~kg}+25 \mathrm{~kg})\end{array}$ & 67 & 29.5 & 4954 \\
\hline $\mathbf{T}_{7}$ & $\begin{array}{l}120 \mathrm{~kg} \mathrm{RDN} \text { at LCC } 4-\mathrm{RDN} \text { applied as } 3 \text { equal splits }\left(1 / 3^{\text {rd }}\right. \\
\left.\text { basal }+1 / 3^{\text {rd }}+1 / 3^{\text {rd }}\right)\end{array}$ & 67 & 32.4 & 5891 \\
\hline $\mathbf{T}_{8}$ & $\begin{array}{l}150 \mathrm{~kg} \text { RDN at LCC } 4-\text { RDN applied as } 1 \text { basal }+2 \text { equal splits ( } 1 / 2 \\
\left.\text { basal }+1 / 4^{\text {th }}+1 / 4^{\text {th }}\right)\end{array}$ & 68 & 33.6 & 5893 \\
\hline $\mathbf{T}_{9}$ & $\begin{array}{l}150 \mathrm{~kg} \mathrm{RDN} \text { at LCC } 4-\mathrm{RDN} \text { applied as } 1 \text { basal }+3 \text { equal splits ( } 1 / 2 \\
\text { basal }+25 \mathrm{~kg}+25 \mathrm{~kg}+25 \mathrm{~kg})\end{array}$ & 67 & 34.3 & 6533 \\
\hline & $\mathrm{SE}(\mathrm{m}) \pm$ & 1.64 & 1.08 & 309.8 \\
\hline & $\mathrm{CD}(\mathrm{p}=0.05)$ & 4.93 & 3.23 & 928.5 \\
\hline & $\mathrm{CV} \%$ & 4.3 & 6.1 & 10.6 \\
\hline
\end{tabular}


Highest dry matter $\left(11246 \mathrm{~kg} \mathrm{ha}^{-1}\right)$ of rice was recorded with $T_{9}$ and was on par with $T_{2}$. While lowest (5208 $\mathrm{kg} \mathrm{ha}^{-1}$ ) was recorded with $\mathrm{T}_{1}$ (No Nitrogen). Treatments imposed based on LCC-4 resulted in higher dry matter than LCC-3. As nitrogen could enhance tillers production, leaf area development and its translocation to panicles at reproductive stage thereby total dry matter production also increased with increased level of nitrogen. Similar findings were reported by Malik et al., (2014) and Lampayan et al., (2010).

Increase in number of tillers varied in accordance with the quantity of $\mathrm{N}$ applied, higher value recorded in treatments receiving higher quantity of $\mathrm{N}$ application. At harvest the highest number of tillers $\mathrm{m}^{-2}$ were noticed with $\mathrm{T}_{9}$ (339). While lowest was recorded with (242) was recorded with $\mathrm{T}_{1}$ (No Nitrogen). Tillers $\mathrm{m}^{-2}$ in $\mathrm{T}_{9}$ increased by 3 and $7 \%$ over farmers and recommended practice respectively. Ahmed et al., (2005) found higher number of tillers with higher dose of $\mathrm{N}$ application.

$\mathrm{T}_{3}$ (Farmers practice with180-80-40 Kg N, $\mathrm{P}_{2} \mathrm{O}_{5}, \mathrm{~K}_{2} \mathrm{O}$ ha $^{-1}$ ) took more time for $50 \%$ flowering (70 DAT) \{Table.2\}. This might be due to availability of excess nitrogen that had led to prolonged vegetative growth, thus resulting in delayed flowering. While $\mathrm{T}_{1}$ (No Nitrogen) registered earliness in days to $50 \%$ flowering (60 DAT) due to inadequate nitrogen availability at all crop growth stages that had hastened flowering.

Highest SPAD meter reading (36.0) was observed with $\mathrm{T}_{3}$ (Farmers practice with 18080-40 Kg N, $\mathrm{P}_{2} \mathrm{O}_{5}, \mathrm{~K}_{2} \mathrm{O}$ ha $^{-1}$ ). While lowest (23.2) was recorded with $\mathrm{T}_{1}$ (No nitrogen). This may be due to application of more quantity of nitrogen which enhanced production of leaf $\mathrm{N}$ concentration and chlorophyll content that ultimately resulted in more SPAD reading (Islam et al., 2004).
Effect of LCC based $\mathrm{N}$ management on yield of rice

Highest grain yield $\left(6,533 \mathrm{~kg} \mathrm{ha}^{-1}\right)$ was recorded with $\mathrm{T}_{9}$ \{Table.2\} which was on par with $\mathrm{T}_{3}$. While lowest grain yield $(2,474 \mathrm{~kg}$ $\mathrm{ha}^{-1}$ ) was recorded with $\mathrm{T}_{1}$ (No Nitrogen). The maximum yield was recorded in $\mathrm{T}_{9}$ which is based on LCC, but it was statistically on par with the yield recorded in Farmers practice with saving of $16.7 \%$ nitrogen and gave $4 \%$ more yields than farmers practice.

The application of $\mathrm{N} @ 120 \mathrm{~kg} \mathrm{ha}^{-1}$ under LCC guidance accounted for lower values of grain yield which could be attributed to inadequate $\mathrm{N}$ to meet the crop needs but have saved $20 \%$ of nitrogen over $150 \mathrm{~kg} \mathrm{~N} \mathrm{ha}^{-1}$. Farmers and recommended practice, though received a total of 180 and $120 \mathrm{~kg} \mathrm{~N} \mathrm{ha}^{-1}$ in three splits at fixed intervals, recorded on par values for yield parameters and yield than LCC based $\mathrm{N}$ application. This could be due to low availability of $\mathrm{N}$ at grain filling phase of the crop. Kenchaiah et al., (2000) also found higher grain yield under LCC based N management than the blanket recommendation.

The present study concluded as more than $50 \%$ of applied $\mathrm{N}$ is lost due in part to the lack of synchrony of plant $\mathrm{N}$ demand with $\mathrm{N}$ supply. The LCC is simple and easy-to-use tool. The LCC based management in rice suggests that $\mathrm{N}$ application can be saved with no yield lose by appropriately revising the fertilizer recommendation. There is considerable opportunity to increase farmers yield through improved $\mathrm{N}$ management with the LCC.

\section{References}

Abrol,Y.P., Raghuram, N and Sachdev, M.S. 2007. Agricultural nitrogen use and its environmental implications. 
International publishing home Private limited, New Delhi. 29-54.

Ahmed, M., Islam, M and Paul, S. K. 2005. Effect of Nitrogen on Yield and Other Plant Characters of Local T. Aman Rice, Var. Jatai. Research Journal of Agriculture and Biological Sciences. 1(2): 158-161.

Ali, M.A., Ladha, J.K., Rickman, J., Lales, J.S and Alam, M.M. 2012. Evaluation of drill seeding patterns and nitrogen management strategies for wet and dry land rice. Bangladesh Journal of Agricultural Research. 37(4): 559-571.

Directorate of Economics and Statistics (DES). Agricultural statistics at a glance, 2016-2017 Report

Islam, M.S., Bhuiya, M.S.U and Rahman, S. 2004. Evaluation of SPAD and LCC based nitrogen management in rice (Oryza sativa L.). Bangladesh Journal of Agricultural Research. 34(4): 661672.

Kenchaiah, K., Veeranna, H. K and Devaraju, K. M. 2000. LCC and SPAD based N management under different methods of sowing in rice. In: Abstracts of the 3rd CREMNET Workshop cum meeting in direct seeding and seeders in Rice, Mysore. p. 9.

Kropff, M.J., Cassman, K.G., Van Laar, H.H and Peng, S. 1993. Nitrogen and yield potential of irrigated rice. Plant Soil Journal. 155/156: 391-394.

Lampayan, R.M., Bouman, B.A.M., De Dios, J.L., Espiritu, A.J., Soriano, J.B., Lactaoen, A.T., Faronilo, J.E and Thant, K.M. 2010. Yield of aerobic rice in rainfed lowlands of the Philippines as affected by nitrogen management and row spacing. Field crops research. 116 (1-2):165-174.

Malik, T.H., Lal, S.B., Wani, N.R., Amin, D and Wani, R.A. 2014. Effect of different levels of nitrogen on growth and yield attributes of different varieties of basmati rice (Oryza sativa L.). International Journal of Scientific and Technology Research. 3(3): 444-448.

Patel, P.D., Patel, M.V., Ombase, K.C., Mevada, K.D., Patel, A.P and Lakum, Y.C. 2018. Real Time Nitrogen Management through Organic and Inorganic Sources in Wheat. Journal of Pure and applied Microbiology. 12 (2):1001-1010.

Season and Crop report, Telangana. 2016-17

Shrestha, R.K and Maskey, S.L. 2005. Review paper: Associative Nitrogen Fixation in Lowland Rice. Nepal Agricultural Research Journal.6:112121.

\section{How to cite this article:}

Bhavana. B., P. Laxminarayana, A. Madhavi Latha and Anjaiah. T. 2020. Judicious Nitrogen Management using Leaf Colour Chart for Enhancing Growth and Yield of Short Duration Transplanted Rice (Oryza sativa L). Int.J.Curr.Microbiol.App.Sci. 9(06): 2850-2856. doi: https://doi.org/10.20546/ijcmas.2020.906.345 